\title{
Entrepreneurship Management Practices in Creating Effective Schools
}

\author{
D. Ayub ${ }^{1} \&$ Norasmah Othman ${ }^{2}$ \\ ${ }^{1}$ Faculty of Teacher Education, University of Riau, Indonesia \\ ${ }^{2}$ Faculty of Education, Universiti Kebangsaan Malaysia, Malaysia \\ Correspondence: D. Ayub, Faculty of Teacher Education University of Riau, Indonesia. E-mail: \\ uptppl@yahoo.co.id
}

Received: August 1, 2013 Accepted: August 16, 2013 Online Published: August 30, 2013

doi:10.5539/ass.v9n12p69 URL: http://dx.doi.org/10.5539/ass.v9n12p69

\begin{abstract}
The purpose of this study was to examine the relationship and contribution of successful entrepreneurial management practice in developing an effective school. The characteristics of successful entrepreneurs include the desire for excellence, determination, self-control, and innovative. Meanwhile, the characteristics of effective schools include commitment, academic achievement, community support, and the quality of graduates surveyed from the perspective of administrators as administrators plays an important role in the management to form an effective school. This study used a survey method using questionnaires. The study sample involving 180 school administrators is randomly selected from 72 schools. The results showed a significant relationship between management which is based on the characteristics of a successful entrepreneur with the establishment of an effective school. Meanwhile, entrepreneurial management features give a significant contribution in the development of an effective school. The implications of this study indicate that successful entrepreneurial management practice should be integrated in the management style and management culture in schools.
\end{abstract}

Keywords: school administrators, management, characteristics of successful entrepreneurs, entrepreneurship, effective schools

\section{Introduction}

Nowadays, it is becoming increasingly difficult to ignore the importance of both entrepreneurship and social areas in school administration (Kyeyune, 2008). Sudarwan (2006) claims that school should learn a lot from the world of entrepreneurship to boost morale in planning and implementing educational programmes as entrepreneurship has become a domestic and international issue. Hoy \&Miskel (2001) says that with the spirit of entrepreneurship, the achievement in performance of principals and teachers can be realized by the principal as the administrator, besides making an offer in black and white on minimum employment standards that he requires.

The school is a place where knowledge is transferred formally between teacher and student (Kuncel, Hezlett, \& Ones 2004). To make the transfer process run smoothly, Koh (2002) and Mujis\& Harris (2003) says that many other elements, including a good curriculum, adequate staff, buildings and equipment, are necessary. Azman (2001) and Marzano, Waters \& McNulty (2005) argued that school concept becomes more complex when it is associated with the concept of administration, because in today's world, administration interests are always changing in every time and every situation occurring in the organization.

Effective schools are required by each component of society, whether the component of the school community of students, teachers, administration, principals and representatives, or the entire community in a broader sense (FitriRasmita 2009). Community pay great attention to the quantity and quality of graduates, qualified for graduate school can open new enterprises and do not work for monthly wages (Gronn 2003). Furthermore, Harris (2002) and Marzano, Waters, \& McNulty (2005) contend that as an educational institution, the school is the place to implement the teaching and learning process. The vision of the school can be effectively achieved through learning activities that aim at producing outstanding and high quality graduates (Deal et al., 1999).

Basically, the purpose of school education is to ensure the effectiveness of teaching and learning, and it is the responsibility of the school leadership to create and maintain a conducive atmosphere for both learning and teaching (Wina, 2009). Further, Foo (2003) and Daresh (2001) pointed out that many administrators support outdated approach of management as the best way to manage a school. A wise administrator has updated 
knowledge and enough training, allowing them to practice certain features in the management of a school (Dunford, Fawcett \& Bennett 2000).

Chin \& Phillips (2004) put forward that a school's main function is to perform tasks for humanitarian process and to humanize mankind. According to Nur (2009) and Akyeampong (2004), although the features of the school's task and outcome is different from which of the industry, the entrepreneurial approach can be applied in school management. According to Pihkala (2008), the principal, teachers, parents associations and other stakeholders of the school should have the capability to implement the entrepreneurial approach. In addition to this, Sudarwan (2006) argues that a school can learn from entrepreneurial experience by practicing the methods done by successful entrepreneurs to establish an effective school.

Darmaningtyas (2004) says that the task of a school administrator in managing a school is more complicated today. Vishalache (2005) and Syaiful (2003) concurred that an administrator's role in organizing and leading the school is becoming more complicated as there has been a number of changes in the education field. Therefore, according to Mulyasa (2011) the management and leadership system of a school needs to apply a new approach, namely entrepreneurial approach. Heflin (2011) argues that school administrators should focus on entrepreneurial approach by practicing in the ways of successful entrepreneurs to create effective schools.

School administrators' ability to effectively practice certain ways can create an effective school, as long as they work hard and are enthusiastic in organizing a school (Rohiat 2008). Alvy\& Robbins (2005) says that the school will become effective when the administrators have administrative skills similar to those of successful entrepreneurs.

\subsection{Effective School}

The concept of an effective school gives the impression on the features that are found most often in school administration (Cavallo, Rozman, \& Potter 2004). Poster (2000) claims that school effectiveness can be understood by reflecting on the features of effective school which have been put forward by many experts. Past researches on effective schools have identified a number of features of an effective school; Salfen (2004) and Syaiful (2009) have done a summary of research on effective schools in the United States and the United Kingdom by showing a lot of factors that effective schools are based on; however, according to them, these factors are not exhaustive or related to each other.

Mortimore et al. (1995) found that in effective schools, students are more progressive and advanced when they initially enter a school. This means that effective schools have added values towards the students' output compared with other schools which have lower levels of input, or students who essentially have the same ability and potential. This demonstrates that different aspects of performance among schools should also be taken into account in determining the effectiveness of a school compared to other schools, due to the existing level of capacity or initial state when a child enters school. Meanwhile, Taylor (1999) argues that in an effective school, all resources are organized and utilized to ensure that all students, regardless of ethnic group, gender, or socio-economic status, can learn the essential curriculum materials in school.

Sergiovanni (1996) explains that there are eight criteria to measure effectiveness: (i) an increase in test scores, (ii) an increase in attendance, (iii) an increase in the number of writing assignments and homework; (iv) an increase in the allocation of time for Math, English, Science and History; (v) the involvement of community and parents; (vi) the involvement of students in co-curricular activities; (vii) award and recognition for students and teachers, and (viii) quality support for special students. Salfen (2004) refering to Edmonds (1979) says that there are five features of an effective school, namely: (i) the principal's leadership and attention on the quality of teaching, (ii) a deep understanding of teaching, (iii) a comfortable and orderly climate for the continuity of teaching and learning, (iv) an expectation that all students at least will master a specific knowledge, and (v) student assessment which is based on the measurement of student learning outcomes.

According to the Ministry of Education (1999), effective education can be seen from the quality characteristics, namely: First, students show a high level of mastery on learning tasks that must be mastered in accordance with the aims and objectives of education among which are academic learning outcomes expressed in academic achievement. Second, learning outcomes are appropriate with student needs in life so that by learning, students not only know something, but also be able to do something that works in life. Third, learning outcomes are appropriate with or relevant to the particular demands of the workplace environment. Based on this perspective, the Department of Education (2002) says that effective schools provide: (i) educational services for students; (ii) management and student services, (iii) equipment and school supplies; (iv) programmes and financing, (v) opportunities for community participation, and (vi) the school culture. 
Sergiovanni (2000) describes the basic concepts of effective schools, namely: (i) the teachers prepare students well, and report in a systematic and orderly way, and they are satisfied with the performance of the school from all the hard work, (ii) the students are conditioned to spend about two hours every night to complete their homework; and the students voluntarily borrow more books from the library compared to other similar schools, and (iii) the parents show high enthusiasm to send their children to the school. Mortimore (1995) expressed 11 characteristics of effective schools, namely: (i) professional leadership, (ii) sharing of insights and objectives, (iii) learning environment, (iv) focus on the teaching and learning process, (v) teaching with objectives; (vi) high expectation of success; (vii) positive reinforcement, (viii) monitor progress, (ix) the rights and obligations of students, (x) the home-school relationship, and (xi) learning organization.

According to Ministry of Education(1999), the characteristics of effective schools as surveyed from the perspective of administrative work to be done at school, are: (i) the administrator must have a strong commitment to improve the school, (ii) the administrator must ensure the student's academic performance is good in each test, (iii) the administrator should be able to include parents and community's participation to support programmes designed for the school development, and (iv) the administrator must make efforts to ensure the school graduates have good qualities. Furthermore, Hasbullah (2006) reiterates that the administration of an effective school has the following features: all parties are committed to the progress of the school; the students are well-developed in their academic performance, the school and the community collaborates well in their joined efforts for the realization of the school's objectives, and school graduates have good qualities to meet the requirements of the workplace or further education.

Based on the discussions above, this study refers to Mortimore (1995) and Depdikbud (1999) to characterize effective schools: (i) a strong commitment towards professional leadership, shared vision and mission of the school, a conducive learning environment, and a good learning organization, (ii) students' achievement in academic by focusing on the process of teaching and learning, teaching with objectives, and positive reinforcement, (iii) community support; a powerful relationships between the school and parents in monitoring the school's progress on an ongoing basis, and (iv) the quality of graduates; the rights and responsibilities of students, and the high expectations of success.

\subsection{Characteristics of Successful Entrepreneurs Practice}

Alberti, Sciascia, \& Poli (2004), Eman (2008) dan Heflin (2011) state that entrepreneurs are the ones who organize, manage, and dare to bear the risk in creating new businesses and business opportunity; Zimmerer \& Scarborough (2005) look at entrepreneurs as managers and executives. According to Dion (2008) some people who are non-entrepreneurs have the entrepreneurial characteristics, which can be put into practice to achieve the organization's achievements and goals.

Eddy (2009) dan Hoe (2005) defines the entrepreneur as a coordinator and supervisor in the production process, and they are the fourth agent in the production factors (the other three factors of production are land, capital and labor). Schumpeter (1934) as referred to in Buchari (2008) defines the entrepreneur as a creative innovator, as the entrepreneur dares to make reforms or changes to the quality of the goods, create a new method of production, opening up a new market, obtain new sources of supply or form a new organization (Rambat 2007). This view is similar with Drucker (1994) as stated by Suharyadi (2007) that the entrepreneur is someone who is willing to do something new, dares to take risk, do not easily give up, like challenges, responsible for decisions being made, creative and be able to manage the business.

Administrators who adopt practices of successful entrepreneurs will be able to achieve and create effective schools, as mentioned by Zimmerer \& Scarborough (2005) about attitudes and behavior of a successful entrepreneur, namely: (i) a determination to devote all his attention on efforts, (ii) have a good sense of responsibility in controlling the use of resources as well as self-control and being responsible for making sure the business is successful, (iii) always motivated to find opportunities, (iv) resistant to risks and uncertainties, (v) self-confidence as well as optimistic, and have a strong belief for his ability to be successful, (vi) inventive and flexible (vii) always requires a fast feedback to know the outcome of his efforts, (viii) highly energetic, (ix) have the urge to always be superior, and be more successful to rise above the existing standard in doing what he does, (x) future-oriented, (xi) always learn from failure, and (xii) leadership skills. Furthermore, Norasmah (2002) says that characteristically features that encourage entrepreneurial attitudes can be grouped into four categories, namely: (i) desire of excellence, (ii) earnestness in business, (iii) strong self-control or "locus of control" and (iv) innovative.

\section{Problems of Study}

It is important for the heads of school and deputy head of the school to have professional competencies to be 
able to apply entrepreneurial principles. (MOE, 2007 and Dadang, 2010). Foo (2003) and Hamzah (2000) states that as the administrator is also the school leader who must fulfill obligations, develop the school as an organization, and develop the individuals within the organization, as his primary role is to ensure the effectiveness of a school.

The community places great hopes for the school to produce qualified individuals who are knowledgeable, moral as well as skilled (Donaldson, 2006). Administrators as school leaders should have professional skills, assertiveness and aims to manage the school as not everyone has a particular thinking styles and practices in solving problems due to lack of self-awareness (Sudarwan, 2010 dan Walker, 2003).

School administrators, such as the heads of school and their representatives are required to perform certain best practices, keep to the school's vision, competent and thus increase the quality of the staff to create effective schools. To achieve this aspiration, the administrator should overcome any weaknesses in his leadership and take the responsibility to lead the school by practicing the habits of successful entrepreneurs so that effective schools are actualized. Therefore, two questions that need to be asked are: whether the use of successful entrepreneurs' best practices, in the administrators' perspective, is related to the effectiveness of a school, and how far does the use of successful entrepreneurs' best practices contribute to the school's effectiveness.

\section{Aim of Study}

The purpose of this study was to determine the relationship and contribution of successful entrepreneurial management practices against the characteristics of effective school according to the administrator's perspective, In Kota Pekanbaru, Riau Indonesia. This study was also conducted with the aim to determine the relationship between successful entrepreneurial management practices (Successful Entrepreneurs practice) with effective school according to an administrator's perspective. This study also investigated the extent of the contribution of successful entrepreneurial management practices on effective school according to an administrator's perspective.

\section{Methodology}

Questionnaires were used as the main instrument in the survey methods undertaken. Data were obtained from administrators' perspective about the characteristics of successful entrepreneurial practices and effective school. Pilot test was conducted on 60 respondents to test the validity and reliabilities of the items in the questionnaire. All items have good validity and reliability as the correlation of the item score and total score exceeds the value adopted which is 0.254 . Cronbach Alpha reliability values obtained was 0.95-0.97 which is at a high level of reliability index adopted (Sugiyono, 2008; Nunally \& Bernstein, 1994; Mitchell \& Jolley, 2004; Mohd Majid, 2005).

176 principals and 4 assistant principals were recruited for this study from a population of 360 school administrators from 72 schools across Kota Pekanbaru, Riau Indonesia, with reference to Isaac \& Michael's (1981) model with 5\% error rate. Pearson correlation (r) was used to determine the relationship between successful entrepreneurial practices and the effective school from the perspective of school administrator; and to interpret the relationship between the two variables with reference to Riduwan \& Sunarto (2009).Next, regression test was used to see the extent of contribution by successful entrepreneurial practices to the school effectiveness.

\section{Findings and Discussions}

The aspects of successful entrepreneurs practices examined include the following: desire for excellence, dedication, having self-control, and innovative. While the aspects of effective schools include the following: commitment, academic achievement, community support, and the quality of graduates surveyed from an administrator's perspective.

The test results shows a significant positive correlation between successful entrepreneurs practices with effective school based on the administrators' perspective at the $r=0608, \operatorname{Sig}=0.000(p<0.05)$. The strength of the relationship between the two variables is on a high-level interpretation(Riduwan \& Sunarto, 2009). 
Table 1. Correlation between successful entrepreneurs practices and effective school based on the administrators' perspective

\begin{tabular}{lcccc}
\hline Variables & n & r & Sig & Strength of relationship \\
\hline Successful entrepreneurs practices - Effective school & 180 & 0.608 & 0.000 & Strong \\
\hline Significance at $p<0.05$ & & & & \\
$X=$ Successful entrepreneurs practices & & & & \\
$Y=$ Effective school & & & &
\end{tabular}

The contribution of the variable successful entrepreneurs practice to effective school from administrators' perspective as in Table 2, where the value of $t$ at successful entrepreneurs practice was 10.208 with a significance value $=0.000,(\mathrm{p}<0.05)$, so the results shows a contribution of successful entrepreneurs practice towards effective school. The amount of contribution is at $36.90 \%$. This finding indicates that successful entrepreneurs practice is a great contribution to school effectiveness according to the administrator's perspective; and the variable successful entrepreneurs practices is an important variable in determining the level of schools' effectiveness from the perspective of school administrators.

Table 2. Contribution of successful entrepreneurs practices towards effective school based on the administrators' perspective

\begin{tabular}{lccccc}
\hline Model & Standard Error & Beta & t & Sig. & Contribution (\%) \\
\hline Predictor & 5.774 & - & 5.562 & 0.000 & \\
Successful entrepreneurs practices & 0.062 & 0.608 & 10.208 & 0.000 & 36.90 \\
\hline $\mathbf{R}^{2}=0.369$ & & & & & \\
$\mathbf{R}^{2}$ Adjusted $=0.366$ & & & & & \\
Standard Error $=2.607$ & & & & &
\end{tabular}

Based on the analysis, mathematical equations for regression model is as follows:

$$
\hat{y}=32.116+0.608 x
$$

Based on the mathematical equations, successful entrepreneurs practices can be degraded to as large as $0.608 \%$, and effective school from administrators' perspectives will be increased by 32.116 percent.

Related to these findings, Dinham (2004), Cavallo, Rozm \& Potter (2004) and Geelan et al. (2000) say that in organizing and managing the school, the role of the administrator often changes according to the transformation in the educational system of the country, for which administrators must be prepared to face a paradigm shift and must be able to adapt to the transformation taking place, and administrators can use certain practices in the face of arbitrary changes. Administrators' role, according to Goldring \& Rallis (1993), Day (2000) and Johnson \& Kardos (2002) is not limited to the field of administration, but also in the areas of leadership, particularly involving the teaching and learning in the educational institutions to create effective schools.

Successful entrepreneurs practices is an important variable in determining effective schools, and these findings are in line with studies done by Moerdiyanto (2007), Alvy \& Robbins (2005), Triton (2007) and Eddy (2009) that in general, effective schools are related to certain practices planned and done by the administrators with what has been obtained. A school will be deemed effective if there is a strong relationship between what has been planned to do with the results obtained by school based on a particular way of practice by the administrator. According to Kane \& Douglas (2001) the administrators should always have the concept of effective schools in their mind when they carry out their duties, as this concept refers to a school that is able to optimize all inputs and processes to produce qualified school leavers, that signifies the school's performance, especially the academic performance marked by students who possess all the desired competency in teaching.

Successful entrepreneurs' practices contribute substantially to an effective school, and this is in line with Suharno (2008) and Mulyasa (2011) that administrators with certain practices have strong leadership skills, high expectations for student academic achievement, focused on basic skills students and well- organized for a 
healthy school climate.

MOEC (2010) says that an educational administrator should use entrepreneurial skills to manage change and innovation in the organization. School administrators can replicate this model in managing organizations such as schools, by acting as a successful entrepreneur. This suggestion is in line with the ways of administering organizations submitted by Rambat (2007), Eddy (2009) and Benedicta (2003). Furthermore, Zimmerer \& Scarborough (2005), Hisrich, Peters, \& Sheperd (2008) and Nasrullah (2006) says that individuals having the ability as a successful entrepreneur by adopting successful entrepreneurial practies in managing the school, such as doing analysis and synthesis of theories, concepts, facts and schedule, will be capable to work and form an effective school.

The findings of the current study are consistent with those of Nur(2009), Akyeampong(2004), Meng(1996) andBenedicta(2003) who found that one would think of various ways and adopt a certain way of solving problems, which also is the case of school administrators in this study. Norasmah \& Hariyaty (2006) found that principals who have entrepreneurial characteristics and mindset are able to trigger and create excellent activities to be performed in educational institutions.

\section{Implication}

The finding of this study has important implications on the relationship between successful entrepreneurs' practices and schools, as the former contributes greatly to the effective schools according to the perspective of administrators, and hence, successful entrepreneurs' practices is found to be an important variable in determining the level of schools' effectiveness from the perspective of school administrators. Therefore, it is suggested that school administrators, especially in secondary schools adopt successful entrepreneur's practices in their administrative tasks.

Hence, it could conceivably be hypothesized that successful entrepreneurs' practices can be carried out in the school administration. According to Kent (1990) many people who have the potential or are entrepreneurial but do not become entrepreneurs. This opinion is also supported by Nor Aishah \& Faridah (1998) who state that an individual who has the entrepreneurial attitude and spirit always want to be successful and work hard no matter the areas of work, whether they are fishermen, teachers, technicians, administrators or traders. A person who has good entrepreneurial attitude will always succeed in managing one's work in whatever job one does (Marvel, Griffin Hebda \& Vojak, 2007 and Matlay, 2006). In order to achieve the purpose of the school or to build schools, educational institutions are recommended to learn a lot from successful entrepreneurs. (Sudarwan, 2006 dan Norasmah \& Hariyati, 2006).

School administrators are important people in a school so they should be aware of the potential of successful entrepreneurs' practices and their own perspectives towards creating effective schools and use it in the best possible way to improve the condition of their respective school administration. Administrators who adopt successful entrepreneurs' practices will be able to exploit his thoughts, imagination and intuition. Thus, by taking on successful entrepreneurs' practices on a continuous basis, administrators will be able to see opportunities that are invisible to others, and never satisfied with underperformance and often seek to transform towards betterments and improvements.

According to a mindset of an entrepreneur, administrators should strategize to overcome existing problems. Thus, it is hoped that schools will be managed by administrators who have entrepreneurial skills who adopt successful entrepreneurs' best practices to administer and achieve effectiveness in their schools. It is recommended that's these administrators are given training on successful entrepreneurs' best practices through a series of special courses and training for entrepreneurial educators in order to function well in managing their educational institutions. As an individual, administrator should move forward with positive thinking and adopt successful entrepreneurs' best practices and advance their thinking by following any programme or courses that will strengthen their entrepreneurial skills and culture, in order to create effective schools.

Apart from the principals as administrators of the school, other school managers such as Surety Supervisor of Schools, Counseling Teachers, Business and Cooperative Teachers, Subject Teachers in Trade / Business Studies / Economics / Accounting and Entrepreneurship can also apply successful entrepreneurs' best practices together with school administrators towards achieving school effectiveness and for the success of teaching and learning in the classroom and school administrative activities. Besides, they could also adopt the use of successful entrepreneurs' best practices among the students at the beginning level in order to create an effective school. As the process is a challenging one, the administrators should continue to encourage all members of the school to continue having a positive attitude towards effective schools. It is necessary to realize that tasks at school are now very challenging and critical which requires academic leaders to be creative and innovative in efficiently 
organizing the school as effective school's performance will be achieved with great efforts in effective administration.

Teacher Development Department in the Ministry of Education, or Education Quality Assurance Agency should ensure that preparation of programmes, training activities, and courses are well structured in order to motivate teachers and community educators to successfully apply entrepreneurs' best practices. It is imagined that when more of the skilled administrators and educators implement successful entrepreneurs' best practices, it is hoped that more educational institutions such as secondary schools or primary schools would achieve better performance in all aspects since the schools are effective.

This research on successful entrepreneurs' best practices adopted by administrators for the achievement of effective school from the administrator's perspective is a scientific research activities and a dynamic discovery which has opened up extensive questions in need of further investigation. Successful entrepreneurs' best practices can be applied in all types of job, whether in the field of education, or entrepreneurship itself, or other areas provided that the practitioner has a good perspective and attitude in practicing it. In order to gain more benefits within their respective fields, practitioners ought to make a paradigm shift by applying successful entrepreneurs' best practices in dealing with their job.

The findings in this study suggest that the variable successful entrepreneurs' best practices has a potential to contribute extensively towards effective school. Therefore, it should be applied to create organizational excellence. The findings can directly be exploited by anyone at any level of management in any field especially educational management, including teachers, teacher educators or students. The current findings which add substantially to our understanding of the relationship between successful entrepreneurs' best practices and effective school needs to be disseminated in order to enhance educational institutions and ensure the establishment of more effective schools, as well as produce school graduates who are really ready to be employed. These findings can be used as a reference to compile tests kits for the selection of school principals and administrators, including primary school principals and subject teachers, in order to gauge their understanding of successful entrepreneurs' best practices and effective school.

It is suggested that the association of these factors, namely, successful entrepreneurs' best practices and effective school, is further investigated in more detailed in future studies, especially with the purpose of extending contributions to the achievements of effective schools in the field of education locally and internationally.

\section{Conclusion}

The study found that there is a significant relationship between successful entrepreneurs' best practices and effective school according to the administrator's perspective, and successful entrepreneurs' best practices have contributed the most to the effective schools.

The results of this study could further enrich the culture of successful entrepreneurs' best practices among school administrators to create more effective schools from administrators' perspective. This work contributes to the existing knowledge by providing important meaning that consists in successful entrepreneurs' best practices in science, art, events, nature, features, and character of a person who are capable of creatively transforming innovative ideas into the real world.

\section{References}

Akyeampong, K. (2004). Whole school development in Ghana. Background paper for the education for all global monitoring report 2005: The Quality Imperative. UNESCO, New York. Retrieved from http://unesdoc.unesco.org/0014/001466/146616e .pdf

Alberti, F., Sciascia, S., \& Poli, A. (2004). Entrepreneurship education: Notes on an ongoing debate. IntEnt2004 - 14th Annual Intent Conference, University of Napoli Federico II Italy, 4-7 July 2004.

Alma, B. (2008). Keusahawanan. Bandung: Alfabeta.

Alvy, H., \& Robbins, P. (2005). Growing in to leadership. Educational Leadership, (628), 50-54.

Balakrishnan, V. (2005). Work ethics and empowerment within Malaysian schools. Kertas Kerja 2nd Asia Pacific Business Conference. Anjuran Universiti Teknologi Mara. Putrajaya, 1 - 3 September.

Buang, N. A., \& Karim, F. (1998). Status kewujudan elemen-elemen keusahawanan dalam kurikulum pendidikan teknik, vokasional dan keusahawanan tingkatan 5 di sekolah-sekolah menengah. Projek G2/1998. Universiti Kebangsaan Malaysia.

Cavallo, A. M. L., Rozman, M., \& Potter, W. H. (2004). Gender differences in learning constructs, shifts in 
learning constructs, and their relationship to course achievement in a structured inquiry, year-long college physics course for life science majors. School Science and Mathematics, 104(6), 288-300. http://dx.doi.org/10.1111/j.1949-8594.2004.tb18000.x

Chin, T., \& Phillips, M. (2004). Social reproduction and child-rearing practices: Social class, children's agency, and the summer activity gap. Sociology of Education, (773), 185-210. http://dx.doi.org/10.1177/003804070407700301

Danim, S. (2006). Visi baru manajemen sekolah, dari unit birokrasi ke lembaga akademik. Jakarta: Bumi Aksara.

Danim, S. (2010). Otonomi manajemen pendidikan. Bandung: Alfabeta.

Daresh, J. (2001). Beginning the principalship: a practical guide for new school leaders. Ed. Ke 2. Thousand Oaks: Corwin Press.

Darmaningtyas. (2004). Pendidikan yang memiskinkan. Yogyakarta: Galang Press.

Day, D. V. (2000). Leadership development: A review in context. Leadership Quarterly, 11, 581-613. http://dx.doi.org/10.1016/S1048-9843(00)00061-8

Deal et al. (1999). Shaping school culture; the heart of leadership. San Francisco: Jossey_Bass Publisher.

Dinham, S. (2004). The influence of leadership in producing outstanding outcomes in junior secondary education. Paper presented at the British Educational Research Association BERA, Manchester.

Donaldson, G. (2006). Cultivating leadership in schools: connecting people, purpose and practice. New York: Teachers College Press.

Drucker. (1994). Innovation and entrepreneurship, practice and principles. Translated by. Rusdi Naib. Jakarta Gelora Aksara Pratama. Erlangga.

Dunford, J., Fawcett, R., \& Bennett, D. (2000). School leadership. London: Kogan.

Edmonds, R. (1979). Effective schools for the urban poor. Educational Leadership, 37, 15-18 \& 20-24.

Fooi, F. S. (2003). Pengurusan dan keberkesanan sekolah. In Z. A. L. Pihie, \& F. S. Fooi (Eds.), Management and leadership education: one step forward (pp. 166-180). Serdang: Universiti Putra Malaysia Press.

Frinces, H. (2011). Be an entrepreneur: Jadilah seorang wirausaha. Kajian strategis pengembangan keusahawanan. Yogyakarta: Graha Ilmu.

Geelan, D. R., Wildy, H., Louden, W., \& Wallace, J. (2000). Teaching for Understanding and/ or teaching for the examination in high school physics. International Journal of Science Education, 26(4), 447-462. http://dx.doi.org/10.1080/0950069032000097398

Goldring, E., \& Rallis, S. (1993). Principals of dynamic schools: taking charge of change. Newbury Parks: Corwin Press.

Gronn, P. (2003). The New Educational leaders: Changing leadership practice in an era of school reform. London: Paul Chapman Publishing.

Harris, A. (2002). School improvement: What's in it for schools? London: Routledge Falmer. http://dx.doi.org/10.4324/9780203471968

Hasbullah. (2006). otonomi pendidikan. Kebijakan otonomi daerah dan implikasinya terhadap penyelenggaraan pendidikan. Jakarta: Raja Grafindo Persada.

Hasri, S. (2004). Sekolah berkesan dan guru berkesan. Makasar: Yayasan Pendidikan Makasar.

Hisrich, R. D., Peters, P. M., \& Shepard, D. A. (2008). Entrepreneurship. Mc Graw Hill International Edition, Singapore.

Hoe, C. (2005). Asas keusahawanan. Singapore: Thomson Learning.

Hoy, W. K., \& Miskel, C. G. (2001). Educational administration: Theory, Research and Practice. Ed. ke-6. New York: McGraw-Hill, Inc.

Isaac, S., \& Michael, W. B. (1981). Handbook in research and evaluation (2th ed.). California: San Diego Edits Publishers.

Johnson, S. M., \& Kardos, S. (2002). Keeping new teachers in mind. Educational Leadership, 59(6), 13-16.

Kane, T. J., \& Staiger, D. O. (2001). Improving school accountability measures. National Bureau of Economic Research Working Paper 8156, NBER, Cambridge, MA. 
Kent, C. A. (1990). Entrepreneurship education: integrating entrepreneurship in secondary curriculum. Quorum Books. New York: Greenwood Publishing Group.

Kholis, N. (2009). Panduan praktis mengelola lembaga pendidikan. Yogyakarta: Dianloka Pustaka.

Koh, A. (2002). Toward a critical pedagogy: Creating 'Thinking Schools' in Singapore. Journal of Curriculum Studies, (343), 255-264. http://dx.doi.org/10.1080/00220270110092608

Konting, M. M. (2005). Kaedah Penyelidikan Pendidikan. Kuala Lumpur: Dewan Bahasa dan Pustaka.

Kuncel, N. R., Hezlett, S. A., \& Ones, D. S. (2004). Academic performance, career potential, creativity, and job performance: can one construct predict them all? Journal of Education Psychology, 75, 148-161.

Kyeyune, R. (2008). Strategy for school leadership development in Africa; Learning from collaborative experience and research. A paper presented at the 5th ACP Conference, Kampala, Uganda.

Lupiyoadi, R. (2007). Entrepreneurship, from mindset to strategy. Jakarta: Lembaga Penerbit Universitas Indonesia.

Marvel, M. R., Griffin, A., Hebda, J., \& Vojak, B. (2007). Examining the technical corporate entrepreneurs' motivation: voices from the field. Ent. Theor. Pract., (315), 753-768. http://dx.doi.org/10.1111/j.1540-6520.2007.00198.x

Marzano, R. J., Waters, T., \& McNulty, B. A. (2005). School leadership that works: From research to results. Aurora, CO: Mid-Continent Research for Education and Learning.

Matlay, H. (2006). Researching entrepreneurship and education Part 2: what is entrepreneurship education and does it matter? Education + Training, 48, 704-718.

Meng Liang, T. W. (1996). Entrepreneur, Entrepreneurship and Enterprising Culture. Paris: Addison-Wisley Publishing Company.

Ministry of Education. (1999). Pembangunan pendidikandankebudayaanmenjelang era tinggallandas. Jakarta: Ministry of Education, Indonesia.

Ministry of Education. (2002). Memiliki dan melaksanakan kreativitas, inovasi dan jiwa keusahawanan. Directorate General, Directorate of Elementary and Secondary Education, First Level Continuing Education, Jakarta.

Ministry of Education. (2007). Keusahawanan sekolah. Training materials for competency building for candidates of school heads/principals. Jakarta.

Ministry of Education. (2010). Konsep Dasar Keusahawanan. Module 2. Jakarta: Directorate of Courses and Institutional, Director General of Non-Formal and Informal Education.

Mitchell, M., \& Jolley, J. (2004). Research design explained. Ed.ke-5. New York: Thompson Learning.

Moerdiyanto. (2007, June 22-24). Manajemen sekolah Indonesia yang berkesan melalui penerapan total quality management. Makalah Seminar Penang, Malaysia.

Mohamed, H. (2000). Pembangunan Sekolah Berkesan Dalam Konteks Sekolah Berwatak, Konsep Dan Komitmen.

Mortimore, P., Sammons, P., \& Hillman, J. (1995). Key Characteristics of Effective Schools. Working Paper for Seminar on Effective Schools, Ministry of Education Malaysia13-14 Julai 1995 di Institut Aminudin Baki,. Ministry of Education Malaysia, Sri Laying, Genting Highland, Pahang.

Mujis, D., \& Harris, A. (2003, October). Teacher Leadership-Improvement through Empowerment? An Overview of the Literature. Educational Management Administration \& Leadership, 31, 437-448. http://dx.doi.org/10.1177/0263211X030314007

Mulyasa. (2011). Manajemen dan kepemimpinan kepala sekolah. Jakarta: Bumi Aksara.

Nugraha, D. A. (2008). 8 Revolusi sikap menjadi entrepreneur. Jakarta: Elex Media Komputindo-Kompas Gramedia.

Nunally, J., \& Bernstein, I. (1994). Psychometrictheory. Ed.ke-3.NewYork: McGraw Hill.

Omar, A. C. (2001). Pengurusan di Malaysia dari perspektif Islam. Kuala Lumpur :DewanBahasa dan Pustaka.

Othman, N. (2002). Keberkesanan program usahawan muda di sekolah menengah. Ph.D. Thesis Universiti Putra Malaysia. 
Othman, N., \& Wahid, H. A. (2006). Ciri-ciri keusahawanan dan gaya pemikiran keusahawanan pengetua. Jurnal Pengurusan dan Kepimpinan Pendidikan. Jilid 16 Bil.01 13-38. Malaysia: Institut Aminuddin Baki.

Pihkala, J. (2008). Changes in entrepreneurship intentions during polytechnic education available in Finnish. Opetusministeriön Julkaisuja, 1.

Poster, C. (2000). Gerakan menciptakan sekolah unggul. Jakarta: Lembaga Indonesia Adidaya.

Rasmita, F. (2009). Pintar soft skills membentuk pribadi unggul. Jakarta: Baduose Media.

Riduwan, \& Sunarto. (2009). Pengantar statistika untuk penelitian. Bandung: Alfabeta.

Riyanti, B. P. D. (2003). Keusahawanandarisudutpandangpsikologikepribadian. Jakarta: Grasindo.

Rohiat. (2008). Manajemen sekolah, teori dasar dan praktik. Bandung: Refika Aditama.

Sagala, S. (2003). Administrasi pendidikan kontemporer. Bandung: Alfabeta.

Sagala, S. (2009). Kemampuan profesional guru dan tenaga kependidikan. Bandung: Alfabeta.

Salvato, C., Sciascia, S., \& Alberti, F. G. (2009). The microfoundations of corporate entrepreneurship as an organizational capability. Int. J. Ent. Inov., (104), 279-289.

Sanjaya, W. (2009). Strategi pembelajaran Berorientasi pada Standar Proses Pendidikan. Jakarta: Kencana Prenada Media Group.

Schumpeter, J. (1934). Theory of economics development: an inquiry into profits, capital, credit, interest and the business cycle. Cambridge: Harvard University Press.

Sergiovanni, T. J. (1996). Professional supervision in teacher education. Cambridge: University Press.

Sergiovanni, T. J. (2000). Rethinking leadership. A Collection of Articles by Thomas J. Sergiovanni, Hawker Brownlow Education: Melbourne.

Soegoto, E. S. (2009). Entrepreneurship, menjadi pebisnis ulung. Jakarta: Elex Media Komputindo.

Sugiyono. (2008). Metode penelitian pendidikan: Pendekatan Kuantitatif, Kualitatif, dan R\&D. Bandung: Alfabeta.

Suhardan, D. (2010). Manajemen pendidikan. Bandung: Alfabeta.

Suharno. (2008). Manajemen pendidikan: Suatu pengantar bagi para calon guru. Surakarta: Lembaga Pengembangan Pendidikan dan UPT Penerbitan dan Percetakan UNS.

Suharyadi. (2007). Keusahawanan, membangun usaha sukses sejak usia muda. Jakarta: Salemba Empat.

Suherman, E. (2008). Business Entrepreneur. Bandung: Alfabeta.

Taylor, J. (1999). The effect of Petter Seng's learning organization framework and shared leadership on staff development model. Disertasi Dr. Pendidikan. New York: Fordham University.

Triton, P. B. (2007). Entrepreneurship: Kiat sukses menjadi pengusaha. Tugu Publisher, Yogyakarta.

Walker, S. E. (2003). Active Learning Strategies to Promote Critical Thinking. Journal of Atheletic Training, 38(3), 263-267.

Yusuf, N. (2006). Wirausaha dan usaha kecil. Jakarta; Modul PTKPNF Ministry of Education, Indonesia.

Zimmerer, \& Scarborough. (2005). Pengantar keusahawanan dan manajemen binsnis kecil. Ed. Keempat. PT. Indeks. Jakarta.

\section{Copyrights}

Copyright for this article is retained by the author(s), with first publication rights granted to the journal.

This is an open-access article distributed under the terms and conditions of the Creative Commons Attribution license (http://creativecommons.org/licenses/by/3.0/). 